\section{Testing for Hepatitis C Virus Infection}

Editor - I have read the article "Tests of Liver Injury"1 and found the discussion on hepatitis $\mathrm{C}$ testing of great interest. In our Ugandan (East Africa) patients, we have problems obtaining consistent results with hepatitis $\mathrm{C}$ ELISA kits (HCV EIA). Different HCV EIA kits give varied results making it difficult to confirm the presence of HCV RNA, as some of the negatives are later confirmed positive by the quantitative HCV RNA test.

Although both of the EIA kits screen for the same HCV antigens (the core, NS3, NS4 and NS5) and claim to cover all the 6 known genotypes, neither give consistent results in our populations. One problem is these kits have not been validated in African populations, and we do not know the prevalence of the HCV genotypes circulating in the population. I plan to genotype our population in order to determine whether our use of these EIA kits will provide valid results for our patients, but until the genotype data is available, I am resorting to using the RIBA test to confirm infection and subsequently genotyping positive samples. However, I have been informed the RIBA test is quite expensive compared to HCV RNA testing.

I am, at the moment, uncertain which tests to choose so patients are not diagnosed falsely as positive or negative for $\mathrm{HCV}$ infection. I would appreciate additional discussion from the authors regarding the use and validity of these different tests for HCV infection.

1. Musana KA, Yale SH, Abdulkarim AS. Tests of liver injury. Clin Med Res 2004;2:129-131.

Josephine Birungi, PhD

Uganda Virus Research Institute International AIDS Vaccine Initiative HIV Vaccine Trial Program Entebbe, Uganda Email: JBirungi@iavi.org

\section{Author's Reply}

Editor - We appreciate Dr. Birungi's correspondence and question regarding the appropriate laboratory testing for hepatitis $\mathrm{C}$ virus (HCV). ${ }^{1}$ Her question brings up interesting points for discussion, both clinically and from a laboratory perspective.

Since the discovery of HCV in 1989, there have been at least three generations of enzyme immunoassay (EIA) tests developed to aid in clinical diagnosis and patient management. These tests are used to detect antibody to $\mathrm{HCV}$. Each new generation of test has led to improvements in sensitivity and specificity with the primary goals being reduction of false positives and a decrease in the time it takes to detect seroconversion. As Dr. Birungi correctly points out, there are parts of the world where the performance characteristics of these test kits have not yet been established. This is important because one of the primary determinants of test performance is the prevalence of disease within a population. In 1997, the World Health Organization estimated that $1.17 \%$ of the population in Uganda was infected with HCV. In contrast, during the same time period, the estimate was $1.8 \%$ for the United States and $18.0 \%$ for Egypt. ${ }^{2}$ One would expect to have a higher rate of false positive EIAs in populations with a low prevalence of disease. Laboratory technique is also an important factor. Although EIAs are generally robust tests that can be used successfully in a wide range of laboratories, technical problems can exist and close attention must be directed towards performing the assay as directed by the manufacturer and incorporating quality control procedures. We are not aware that the performance characteristics of the newer generation EIAs are adversely affected by $\mathrm{HCV}$ genotype, however, it is known that the most prevalent genotype in Central Africa has historically been type $4 .{ }^{3}$

Unlike the EIA, qualitative and quantitative HCV RNA tests are technically demanding, and both false positive and false negative results can occur. It has been difficult to standardize nucleic acid testing for $\mathrm{HCV}$ between laboratories, and results have been variable. However, as laboratories gain experience with these assays, it is expected that proficiency will improve. Early generations of quantitative $\mathrm{HCV}$ assays did show some variation based on the genotype that was present. ${ }^{4}$

The recombinant immunoblot assay (RIBA) seems to have limited utility except to confirm positive EIA results in very low prevalence populations, such as blood donors (figure 1). Compared to EIA, RIBA has a better specificity for $\mathrm{HCV}$. RIBA results are reported as positive (two or more antigens present), indeterminate (one positive antigen or two or more positive antigens with positive yeast marker) or negative. Patients with a positive or indeterminate RIBA should undergo qualitative HCV RNA testing, since this test only signifies evidence for $\mathrm{HCV}$ exposure and not necessarily active infection. In most cases, it is more cost-effective to confirm positive EIA results with a sensitive HCV RNA test. For patients with a negative screening EIA, HCV RNA testing should be performed if patients are immunosuppressed and/or have acute hepatitis.

1. Musana KA, Yale SH, Abdulkarim AS. Test of liver injury. Clin Med Res 2004;2:129-131.

2. World Health Organization. Hepatitis C: global prevalence. Wkly Epidemiol Rec 1997; 10:65-72.

3. McOmish F, Yap PL, Dow BC, Follett EA, Seed C, Keller AJ, Cobain TJ, Krusius T, Kolho E, Naukkarinen R, Lin C, Lai C, Leong S, Medgyesi GA, Hejjas M, Kiyokawa H, Fukada K, Cuypers T, Saeed AA, Al-Rasheed AM, Lin M, Simmonds P. Geographical distribution of hepatitis $C$ virus genotypes in blood donors: an international collaborative survey. J Clin Microbiol 1994;32:884-892. 
4. Shuhart MC, Gretch DR. Hepatitis C and G viruses. In: Murray PR, Baron EJ, Jorgensen JH, Pfaller MA, Yolken RH, eds. Manual of clinical microbiology. 8th ed. Washington DC: ASM Press; 2003. 1480-1494.

Kenneth A. Musana, MD Department of General Internal Medicine Marshfield Clinic and Marshfield Clinic Research Foundation Marshfield, Wisconsin

Steven H. Yale, MD, FACP

Director of Clinical Research Marshfield Clinic Research Foundation Marshfield, Wisconsin

Kurt D. Reed, $M D$ Senior Research Scientist Marshfield Clinic Research Foundation Murphy's Sign Marshfield, Wisconsin

Editor - In the article "John Benjamin Murphy (1857-1916)" " we gave a description of performing Murphy's sign that was misleading. On page 111, the statement "Murphy's sign is elicited in patients with acute cholecystitis by asking the patient to take in and hold a deep breath while palpating the subcostal region." In practice, Murphy's sign is performed by palpating the subcostal region during inspiration. If pain is elicited and the patient suddenly stops their inspiratory effort, a positive Murphy's sign has been elicited.

We also add that Dr. Murphy was a lecturer at Rush University and later became professor of surgery at North Western University in Chicago. He was also a member of the College of Physicians and Surgeons from 1884- 1916.

1. Musana K, Yale SH. John Benjamin Murphy (1857 - 1916). Clin Med Res 2005;3:110-112.

Kenneth A. Musana, MD Department of General Internal Medicine Marshfield Clinic and Marshfield Clinic Research Foundation Marshfield, Wisconsin

Steven H. Yale, MD, FACP Director of Clinical Research Marshfield Clinic Research Foundation Marshfield, Wisconsin

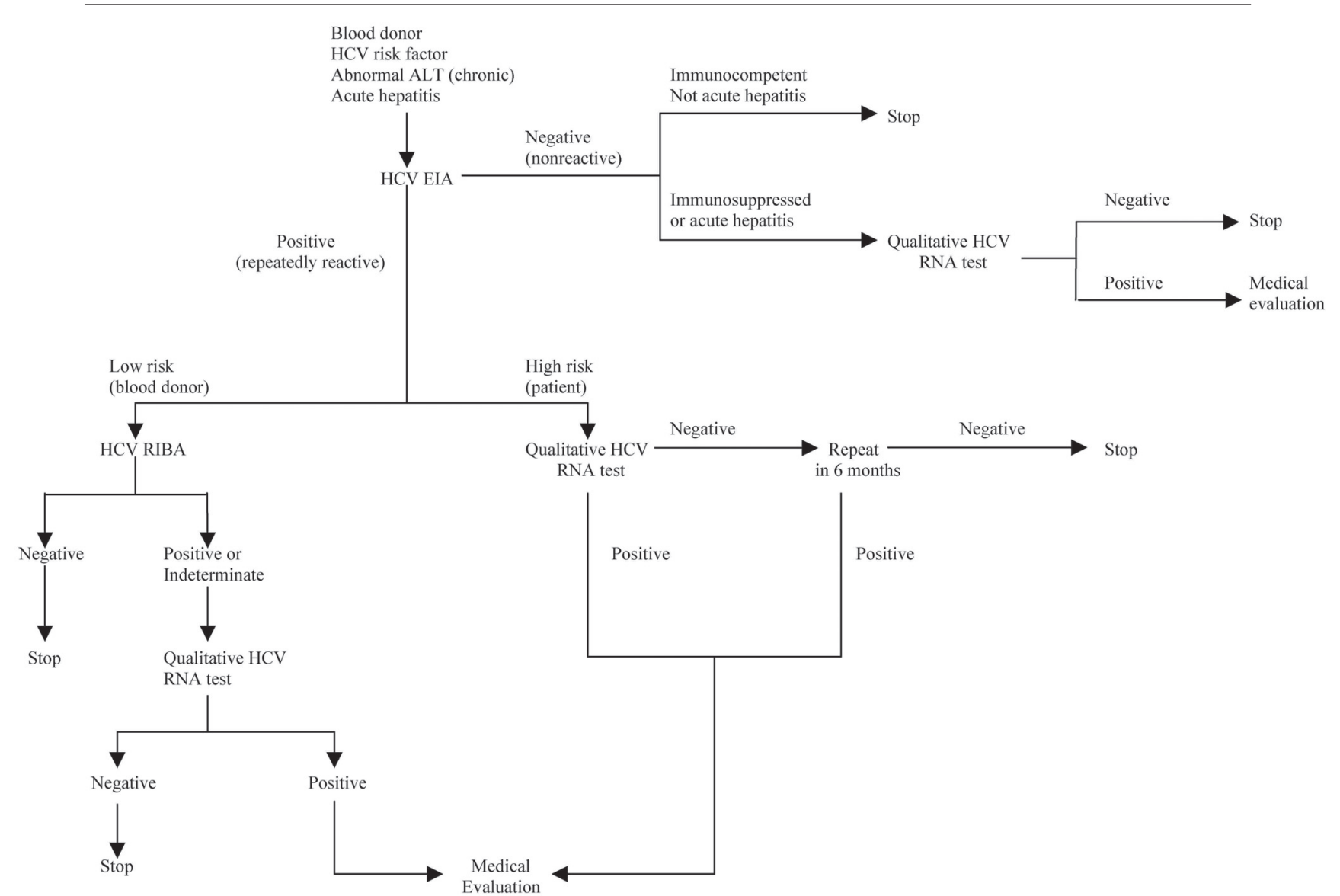

Figure 1. Diagnostic algorithm for HCV testing. Adapted with permission from figure 4, page 1488, Shuhart MC, Gretch DR. Hepatitis $\mathrm{C}$ and $\mathrm{G}$ viruses. In: Murray PR, Baron EJ, Jorgensen JH, Pfaller MA, Yolken RH, eds. Manual of clinical microbiology. 8th ed. Washington DC: ASM Press; 2003. 1480-1494. 